Article

\title{
Development of Paper Sludge Ash-Based Geopolymer and Application to Treatment of Hazardous Water Contaminated with Radioisotopes
}

\author{
Zhuguo Li ${ }^{1}$, Toshihiko Ohnuki ${ }^{2}$ and Ko Ikeda ${ }^{1, *}$ \\ 1 Graduate School of Science and Technology for Innovation, Yamaguchi University, 2-16-1 Tokiwadai, \\ Ube 755-8611, Japan; li@yamaguchi-u.ac.jp \\ 2 Advanced Science Research Center, Japan Atomic Energy Agency, 2-4 Shirakawa Shirane, \\ Tokai-Mura 319-1195, Japan; ohnuki.toshihiko@jaea.go.jp \\ * Correspondence: k-ikeda@yamaguchi-u.ac.jp; Tel./Fax: +81-836-22-8296
}

Academic Editor: Claudio Ferone

Received: 18 May 2016; Accepted: 20 July 2016; Published: 28 July 2016

\begin{abstract}
Ambient temperature geopolymerization of paper sludge ashes (PS-ashes) discharged from paper mills was studied by means of scanning electron microscopy (SEM), X-ray diffraction (XRD), induction coupled plasma atomic emission spectrometry (ICP-AES), and X-ray absorption near edge structure (XANES). Two varieties of alkaline liquors were used in the PS-ash based geopolymers, corresponding to aqueous Na-metasilicate and Na-disilicate compositions. PS-ashes were found to be semi-crystalline and to have porous structures that make it possible to absorb much liquor. Flexural strengths of PS-ash-based geopolymers with liquor/filler ratios (L/F) of 1.0-1.5 ranged from 0.82 to $1.51 \mathrm{MPa}$ at 4 weeks age, depending on PS-ashes and liquors used. The reaction process of the constituent minerals of the PS-ash is discussed. Furthermore, we attempted to solidify hazardous water contaminated with radioisotopes. Non-radioactive strontium and cesium nitrates were added as surrogates at a dosage of $1 \%$ into the PS-ash-based geopolymers. Generally, high immobilization ratios up to $99.89 \%$ and $98.77 \%$ were achieved for $\mathrm{Sr}^{2+}$ and $\mathrm{Cs}^{+}$, respectively, depending on the source of PS-ashes, alkaline liquors, and material ages. However, in some cases, poor immobilization ratios were encountered, and we further discussed the causes of the instability of derived geopolymer gels on the basis of XANES spectra.
\end{abstract}

Keywords: geopolymer; paper sludge ash; radioisotope; radioactively contaminated water

\section{Introduction}

A geopolymerization technique may involve three categories of application. The first is the synthesis of silicates of nanometer scale at temperatures as low as $800{ }^{\circ} \mathrm{C}$ with less alkali contamination [1-4]. The second is the preparation of monolithic materials, potentially replacing Portland cement and recycling various sorts of wastes or by-products [5-18]. The third is the immobilization of hazardous heavy metals or radioisotopes contaminated in sludgy solid wastes, an application dating back to 1988 [19]. On the other hand, there is a liquid type of waste contaminated with radioisotopes awaiting to be treated [20,21]. To immobilize this type of waste by geopolymerization, the liquor/filler ratio (L/F) becomes large. However, if the geopolymer is made from general aluminosilicate powder (e.g., metakaolin and fly ash), a higher L/F would cause bleeding, and hazardous elements accordingly escape from the geopolymer. Although this problem would be solved by using coal fly ash cenospheres or porous glass ceramics [20,21], collecting or producing these materials in large quantities is very difficult and costly. Therefore, most studies are focused on the solid-liquid separation techniques based on zeolite media's absorption [22-24]. Incidentally, this kind of zeolite absorption technique is practically limited to Cs. 
On the other hand, according to literature [25,26], the annual discharge of paper sludge amounts to 3.1-3.8 million tons in Japan as dry-base. To reduce the volume as well as the bad odor, incineration is generally carried out at temperatures $600^{\circ} \mathrm{C}-1000^{\circ} \mathrm{C}$, employing fluidized bed boilers. Accordingly, a huge amount of incineration ash (so-called paper sludge ash, PS-ash in short in the present study) is discharged. Some studies have attempted the recycling of PS-ash; for instance, hydrothermal solidification to produce building materials, solidification materials of soft ground, coagulants for dredging, etc. [27-29]. The PS-ash with high kaolin content has a pozzolanic characteristic [30]. However, beneficial use of the PS-ash on a massive scale is still one of the urgent environmental issues in Japan, as well as globally.

Several years ago, the authors found that the PS-ash can be used to produce geopolymers as active filler, and the geopolymers must have a L/F over 1.0 due to the high water absorption ability of PS-ash. This characteristic makes PS-ash-based geopolymer to be suitable for the disposal of radioactively-contaminated water [31,32]. In the present study, the reaction process of PS-ash-based geopolymer is studied from the aspects of mineralogy. Moreover, in order to clarify the stability of immobilization of radioisotopes, the immobilization ratios of radioisotopes in the PS-ash-based geopolymer is further investigated as a function of material age.

\section{Experimental Procedure}

\subsection{Specimen Preparation and Strength Test}

Three kinds of PS-ash were collected from paper mills in Japan. Their physicochemical characteristics are shown in Table 1. Two kinds of geopolymer liquors were prepared, designated as \#0 and \#1 liquors, respectively. The \#1 liquor was prepared from condensed commercial Na-disilicate liquor $\left(\mathrm{Na}_{2} \mathrm{O} \cdot 2 \mathrm{SiO}_{2} \cdot \mathrm{aq}\right)$ by diluting with deionized water to have a specific gravity (S.G.) of 1.27, corresponding to a $24.25 \%$ concentration of Na-disilicate $\left(\mathrm{Na}_{2} \mathrm{O} \cdot 2 \mathrm{SiO}_{2}\right)$. The $\# 0$ liquor was prepared by mixing the \#1 liquor with $10 \mathrm{M} \mathrm{NaOH}$ solution at a ratio of 3:1 by volume to have a S.G of 1.31, corresponding to a $23.55 \%$ concentration of Na-metasilicate $\left(\mathrm{Na}_{2} \mathrm{O} \cdot \mathrm{SiO}_{2}\right)$.

Plain geopolymer pastes were prepared as tabulated in Table 2 without adding non-radioactive strontium and cesium sources. One hundred grams of each PS-ash was weighed and transferred to a $500 \mathrm{~mL}$ plastic beaker, and was hand-mixed with the alkaline liquors to obtain pastes. Then, the charge was cast into a three-cell type prismatic mold with $20 \mathrm{~mm} \times 20 \mathrm{~mm} \times 80 \mathrm{~mm}$ dimensions and was cured in a $20{ }^{\circ} \mathrm{C}, 100 \% \mathrm{RH}$ chamber overnight. After demolding, the prismatic test pieces were kept curing for 28 days under the same conditions. Then, flexural strength was measured by employing a three-point flexural tester under the conditions of $50 \mathrm{~mm}$ span and $0.2 \mathrm{~mm} / \mathrm{min}$ cross-head speed. Mean fracture load of three test pieces was used to calculate the flexural strength, applying the well-known three-point formula [31]. Bulk densities of the specimens were also measured before the flexural test.

On the other hand, paste specimens were also prepared, containing non-radioactive Sr-nitrate, $\mathrm{Sr}\left(\mathrm{NO}_{3}\right)_{2}$, and Cs-nitrate, $\mathrm{CsNO}_{3}$, together as surrogates. The surrogates and the solidified bodies are called SC and SC-GP in short, respectively. The dosage of each surrogate was $1 \%$ as nitrates against PS-ash weight. After weighing, the charge was bottle-mixed. The other procedures and conditions are the same as for the plain specimens. 
Table 1. Physicochemical characteristics of paper sludge (PS)-ashes used as geopolymer filler, mass \%.

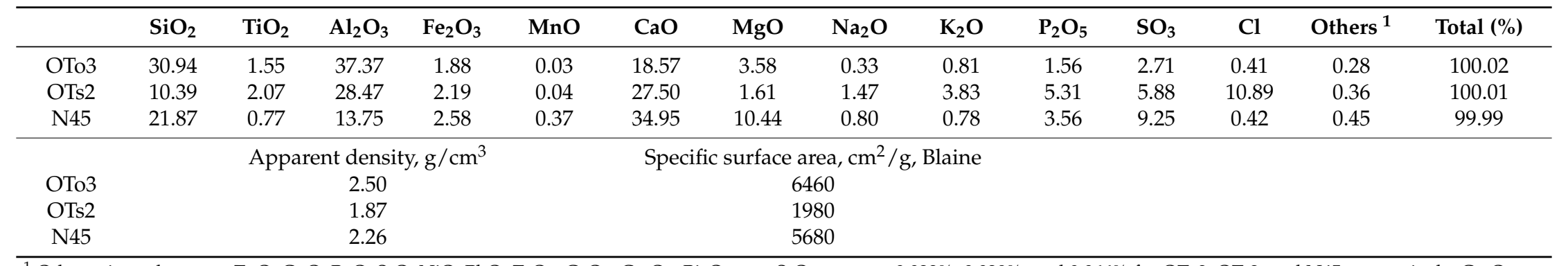

${ }^{1}$ Other minor elements: $\mathrm{ZnO}, \mathrm{CuO}, \mathrm{BaO}, \mathrm{SrO}, \mathrm{NiO}, \mathrm{PbO}, \mathrm{ZrO}_{2}, \mathrm{CeO}_{2}, \mathrm{Cr}_{2} \mathrm{O}_{3}, \mathrm{Bi}_{2} \mathrm{O}_{3}$, etc. SrO contents: 0.023\%, 0.029\%, and 0.066\% for OTo3, OTs2, and N45, respectively. Cs 2 O was not detected within detection limits. LOI, loss on ignition at $1000^{\circ} \mathrm{C}$ : OTo3/6.00 $(1.66) \%$, OTs $2 / 32.57(23.42) \%$, N45/22.10 (12.49)\%, respectively, other than the total. In parentheses $\mathrm{H}_{2} \mathrm{O}(-)$ values determined at $105^{\circ} \mathrm{C}$ are indicated. 
Table 2. Compositions of plain geopolymer pastes, mass \%.

\begin{tabular}{cccccc}
\hline Liquor & L/F $^{\mathbf{1}}$ & Filler & Na-Silicates $^{2}$ & Water & Total (\%) \\
\hline$\# 0$ & 1.50 & 40.00 & 14.13 & 45.87 & 100 \\
& 1.20 & 45.45 & 12.85 & 41.70 & 100 \\
\hline$\# 1$ & 1.50 & 40.00 & 14.55 & 45.45 & 100 \\
& 1.20 & 45.45 & 13.23 & 41.32 & 100 \\
\hline${ }^{1} \mathrm{~L} / \mathrm{F}=$ Liquor $\left(\right.$ Dry Na-silicates + water)/Filler mass ratio ${ }^{2}$ Dry Na-silicates, $\mathrm{Na}_{2} \mathrm{O} \cdot \mathrm{SiO}_{2}$ or $\mathrm{Na}_{2} \mathrm{O} \cdot \mathrm{SiO}_{2}$
\end{tabular}

\subsection{Various Analysis of PS-Ashes and Leaching Test of Surrogates}

The PS-ashes as received were chemically analyzed by X-ray fluorescence (XRF), employing Philips MagixPro (Royal Philips, Amsterdam, Holland) with fundamental parameter methods (FP). Loss on ignition (LOI) was separately determined by heating with an electric furnace at $1000{ }^{\circ} \mathrm{C}$ for $2 \mathrm{~h}$. Furthermore, moisture content was measured with an oven at $105^{\circ} \mathrm{C}$ for $2 \mathrm{~h}$. Apparent densities were determined by a pycnometer. Then, specific surface areas were measured by a conventional Blaine apparatus (Marubishi Kagaku, Tokyo, Japan). Constituent minerals were identified by X-ray diffractometry (XRD), employing Rigaku RINT-2550 (Rigaku, Tokyo, Japan). To avoid reflections from glass, window-type sample holders made of $\mathrm{Al}$ metal were used throughout this measurement. Scanning electron microscopy (SEM) was adopted to observe textures of the PS-ashes, employing Jeol JSM-7600F (Jeol, Tokyo, Japan). XRD technique was also used to analyze the hardened paste specimens.

After 4 weeks aging, the SC-GP and plain specimens were further cured in ambient air for 2 weeks ( $4+2$ week age), 8 weeks (12 week age), and 20 weeks ( 24 week age), respectively, in order to examine the stability of immobilization of the surrogates. After curing, the SC-GP samples were weighted and then crushed to be finer than $4 \mathrm{~mm}$ in size for the leaching test. Twelve point five grams of the crushed sample was immersed into the commercially available buffer solution ( $\mathrm{pH} 4.01$ ) containing phthalic salt, meant to mimic exposure to strong acidic rainfall at disposal sites. There are several methods to evaluate dissolutions as described in literature [31], but the phthalic salt buffer method is adopted as a laboratory scale method for the convenience of our laboratory facilities. The weight of the buffer solution was $125 \mathrm{~g}, 10$ times the sample weight. Then, leaching test was performed in a $250 \mathrm{~mL}$ plastic bottle rotated at $60 \mathrm{rpm}$ for $6 \mathrm{~h}$. Finally, the leachates collected by percolating with filter paper were chemically analyzed by induction coupled plasma atomic emission spectrometry (ICP-AES), employing PerkinElmer, Optima 8300 (PerkinElmer, Waltham, MA, USA). Obtained concentrations of leachates were recalculated on the basis of $125 \mathrm{~g}$ to get leaching weights of the surrogates, while surrogate amounts were calculated to $12.5 \mathrm{~g}$ of SC-GP samples on the basis of filler/Na-silicates/water proportions and the resultant bulk densities of each age shown in Tables 2 and 4 , respectively. Details are as follows:

(1) Bulk densities obtained were regarded as apparent densities of the sample grains with the size of under $4 \mathrm{~mm}$ (Table 4$)$.

(2) Density $\left(\mathrm{D}_{0}\right)$ at 4 week age was disintegrated into filler/Na-silicates/water ratios according to the percentages shown in Table 2. For instance, for series 0-3SC shown in Table 4, $\mathrm{D}_{0}=1.49,1.49$ was revolved into $0.677 / 0.191 / 0.625$. Incidentally, the 4 week curing was performed in air $\left(20^{\circ} \mathrm{C}\right.$, $100 \% \mathrm{RH})$ so that the proportions in Table 2 are maintained in the solidified specimens.

(3) Then, the density $\left(D_{1}\right)$ at $4+2$ week age was recalculated, supposing only moisture water was evaporated during the air dry. For instance, for 0-3SC, $\mathrm{D}_{1}=1.08$, which becomes $0.677 / 0.191 / 0.211$.

(4) Moreover, the proportions of $\mathrm{D}_{1}$ in (3) were converted into percentages. For instance, for 0-3SC, $\mathrm{D}_{1}$ becomes $62.74 / 17.70 / 19.56$, in total $100 \%$.

(5) Finally, the filler amounts in dissolution test samples were obtained. For instance, for 0-3SC, the filler amount is $62.74 \%$. Therefore, in the $12.5 \mathrm{~g}$ samples, the surrogate amount become $78.4 \mathrm{mg}$ for strontium and cesium as nitrates, respectively, since the dosages were $1 \%$ of fillers by mass, irrespective of surrogate species (Table 6). 
(6) The procedure is the same for other prolonged age specimens of 12 and 24 week ages of which bulk densities are indicated as $D_{2}$ and $D_{3}$, respectively (Table 4).

Thus, immobilization ratios were obtained as follows:

$$
\text { Immobilization ratio }(\%)=\left(1-\mathrm{Sr}^{2+} \text { or } \mathrm{Cs}^{+} \text {in } 125 \mathrm{~g} \text { leachate } / \mathrm{Sr}^{2+} \text { or } \mathrm{Cs}^{+} \text {in } 12.5 \mathrm{~g} \text { sample }\right) \times 100
$$

In present study, the surrogates were regarded as a part of alkaline liquors. However, the surrogates' amounts were not taken into account in the above calculations of (2) and (3) since they were very small in amounts.

In addition, X-ray absorption near edge structure (XANES) was attempted to clarify bonding and coordination circumstances of $\mathrm{Sr}^{2+}$ and $\mathrm{Cs}^{+}$incorporated into SC-GP samples. For $\mathrm{Cs}^{+}$, however, it was technically unsuccessful at the moment, due to the duplication of the L-edge of cesium with the K-edge of titanium in X-ray spectra.

\section{Results and Discussion}

\subsection{Characteristics of PS-Ashes}

Chemical compositions of PS-ashes are represented in Table 1. OTo3 has a usual composition. However, the others have unusual compositions. The high content of $\mathrm{Cl}$ in OTs2 would be attributed to refuse derived fuel (RDF), which contains much chlorine and moisture, while the high content of $\mathrm{MgO}$ in N45 to recycled plastic fuel (RPF), which contains much talc, commonly used as a filler in plastic appliances. Both RDF and RPF are used widely in Japan as boiler fuels, together with oils.

To clearly grasp the features of the PS-ashes, the chemical compositions are plotted on the ternary diagram, as shown in Figure 1, in terms of $\mathrm{CaO}-\mathrm{Al}_{2} \mathrm{O}_{3}-\mathrm{SiO}_{2}$ mass ratio. The plots encompass a wide range of PS-ashes. OTo/OTs series are plotted alongside with a trend line parallel to the first hydraulic line running through to the metakaolin point. On the other hand, N-series showed different features, plotted in the vicinity of blast furnace slag (BFS), a member of the first hydraulic line. The former group (OTo/OTs series) can be called high-alumina PS-ash, while the latter group (N-series) can be called low-alumina PS-ash. From another point of view, the PS-ashes can be classified into two groups-Ca-rich and Ca-poor. OTo1 and OTo3 are in the latter group, but the others are in the former group. Readers are kindly requested to refer to our past publication for relevant PS-ash compositions [31].

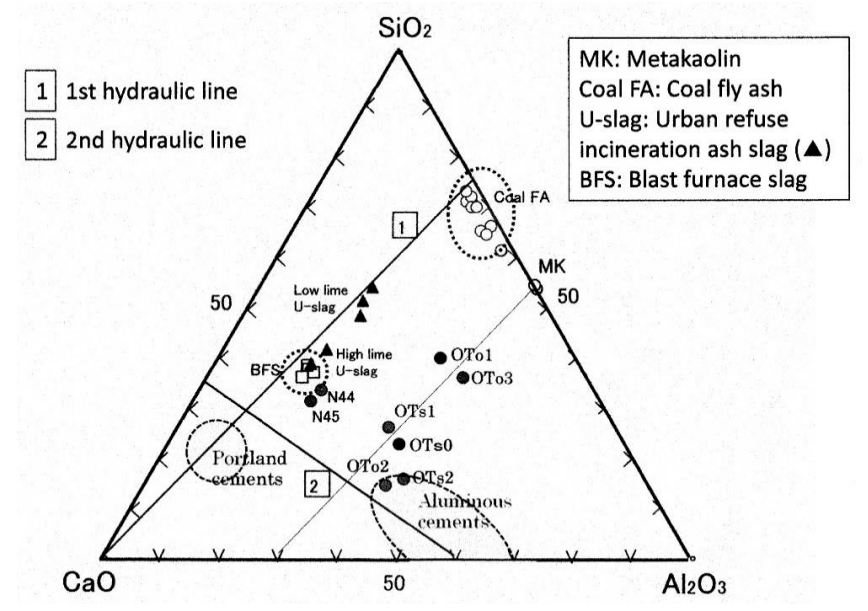

Figure 1. Ternary diagram plots of PS-ash fillers and other fillers studied so far.

SEM images of the PS-ash are represented in Figure 2. Sponge-like porous textures peculiar to gel materials [33] can be seen for all the samples-most clearly for OTo3. Moreover, ettringite prevailed in OTo2 and N45 in acicular to prismatic forms. Particularly in OTs2, some ettringite crystals developed in stout prismatic form. 

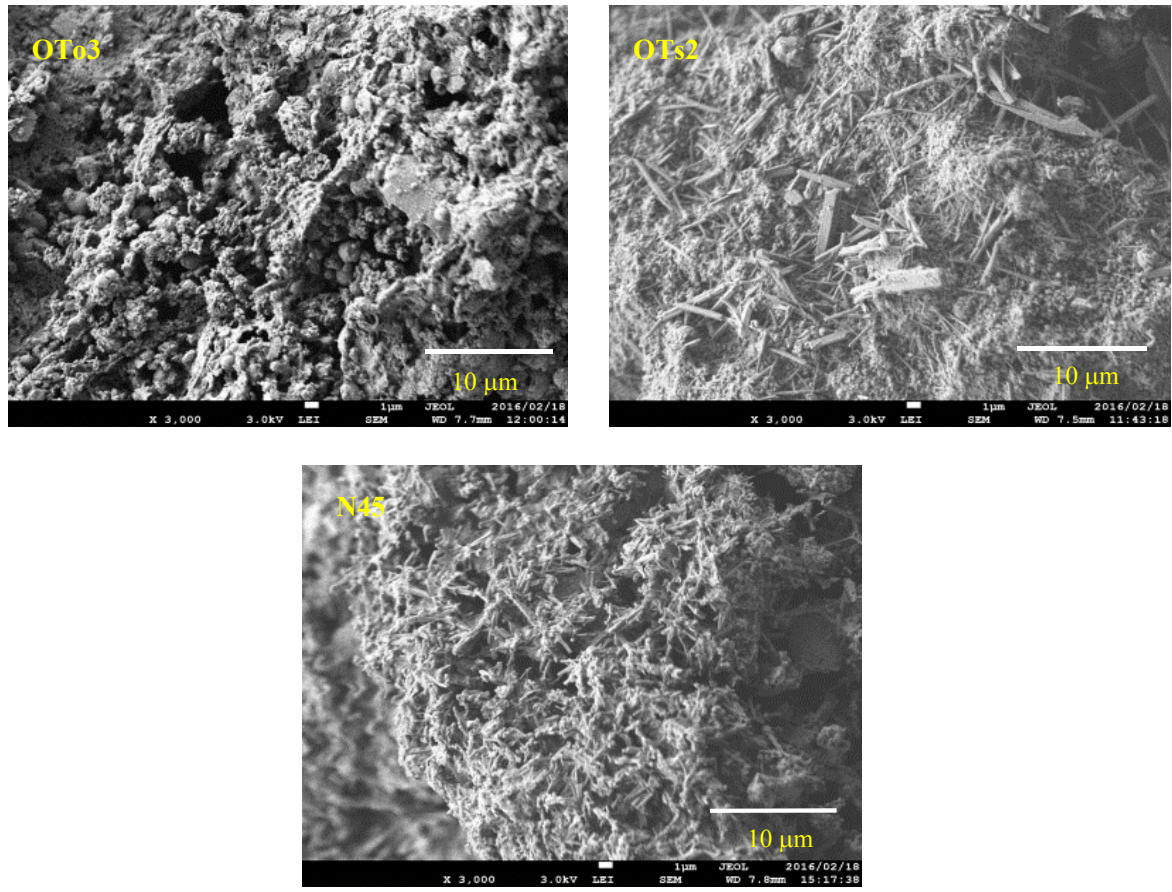

Figure 2. SEM images of the raw PS-ashes.

XRD diagrams of the PS-ash are represented in Figure 3. Calcite, quartz, and anhydrite were identified, irrespective of the PS-ash. In addition, humps are recognized around $2 \theta=20^{\circ}-40^{\circ}$. Particularly, the humps are very clear in OTo3, suggesting the presence of amorphous materials. OTo3 is characterized by less presence of ettringite, while the others (OTs2 and N45) show the pronounced presence of ettringite due to high $\mathrm{SO}_{3}$ contents, in addition to high $\mathrm{LOI}$ and moisture contents, as seen in Table 1.
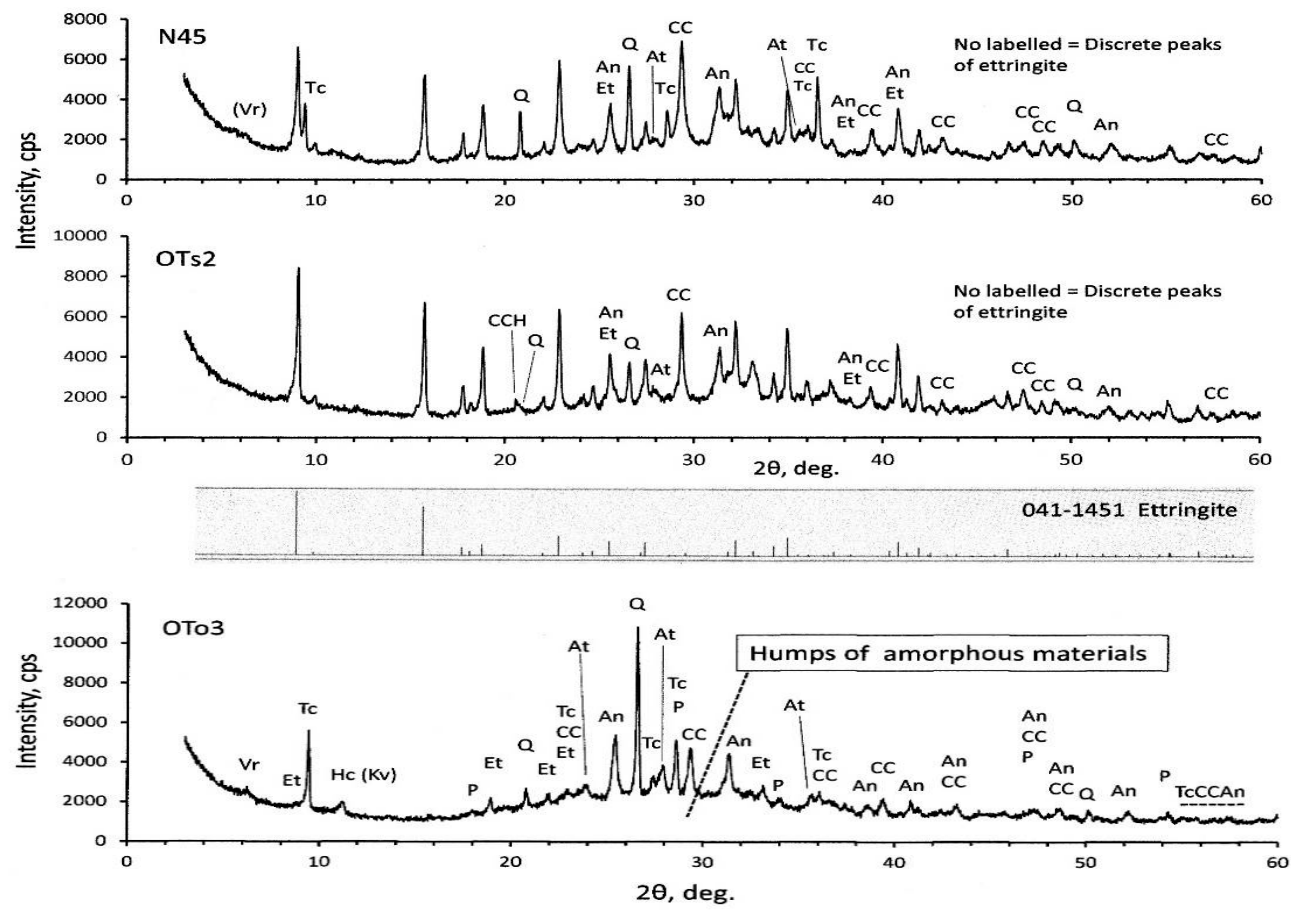

Figure 3. XRD diagram of raw OTo3. Keys refer to Tables 3 and 5. 
It is important to classify the identified minerals on the basis of primary and secondary origins, as classified in Table 3. In OTo3, relict portlandite was detected, indicating that primarily quick lime (CaO) formed in the boiler. Water is generally sprinkled over the ash to prevent the ash from scattering after incineration, or sometimes the ash is pelletized. Accordingly, the quick lime slakes into portlandite and finally turns to calcite, in some cases to vaterite [31], due to reaction with $\mathrm{CO}_{2}$ in air. The ashes derived from plants and woods generally comprise $\mathrm{K}_{2} \mathrm{O}, \mathrm{CaO}$, and $\mathrm{SiO}_{2}$ as main components, in addition to $\mathrm{MgO}, \mathrm{P}_{2} \mathrm{O}_{5}, \mathrm{SO}_{3}$, and $\mathrm{Na}_{2} \mathrm{O}$ as subordinate components [34]. Quartz may generate during the incineration in boilers. Anhydrite is a product of desulfurization. Generally, fluidized bed-type boilers are fed by limestone together with fuel coal for desulfurization, but for paper sludge incinerations, limestone is not required, since paper sludge contains much $\mathrm{CaO}$. Moreover, calcite is usually used as filler and coating materials for ordinary grade paper. Contrary, kaolin or kaolin/calcite mixtures are used for high grade paper. Waste papers are so often fed to boilers as fuel, which also act as moisture absorber of wet paper sludge, so the origin of the $\mathrm{Al}_{2} \mathrm{O}_{3}$ component would be the kaolin. Strictly speaking, the presence of talc is because talc is so widely used as filler materials for paper and plastic appliances, so it remains in the ash of paper sludge, waste paper, and RPF combustions. A small amount of anorthite was identified, of which formation was also reported in literature for the ash from a pressurized fluidized bed-type boiler [16]. Vermiculite and hydrocalumite are secondary minerals formed during the water sprinkling. The presence of kovdorskite is also suspected other than hydrocalumite, judging from the $2 \theta$ positions. OTs 2 and N45 show nearly the same XRD patterns-in which ettringite is prevailed-but talc is lacking in OTs2. It should be noted that hydrocalcite was identified in OTs2, of which the main peak is slightly different from the quartz peak, as indicated in Figure 3. Anorthite is also identified in minor quantities in both OTs2 and N45. Forsterite might be a primary origin, as discussed later in Section 3.3.

Table 3. Summary of XRD results of PS-ashes.

\begin{tabular}{|c|c|c|c|c|c|c|}
\hline \multicolumn{3}{|c|}{ PS-ash Minerls } & \multicolumn{3}{|c|}{ PS-ash } & \multirow{3}{*}{$\begin{array}{c}\text { Remark } \\
\text { In boilers } \\
\text { Liberated } \mathrm{SiO}_{2}\end{array}$} \\
\hline Key & \multicolumn{2}{|c|}{ Minerals of primary origin } & OTo3 & OTo2 & N44 & \\
\hline $\mathrm{Q}$ & Quartz & $\mathrm{SiO}_{2}$ & ++++ & ++ & +++ & \\
\hline An & Anhydrite & $\mathrm{CaSO}_{4}$ & +++ & ++ & ++ & Sulfur capture \\
\hline At & Anorthite & $\mathrm{CaAl}_{2} \mathrm{Si}_{2} \mathrm{O}_{8}$ & ++ & + & + & Recombination \\
\hline Fo & Forsterite & $\mathrm{Mg}_{2} \mathrm{SiO}_{4}$ & - & - & $(+)$ & Recombination \\
\hline \multirow[t]{2}{*}{ Tc } & Talc & $\mathrm{Mg}_{3}(\mathrm{OH})_{2} \mathrm{Si}_{4} \mathrm{O}_{10}$ & +++ & - & ++ & RPF-origin \\
\hline & Amorphous & & ++ & + & + & Recombination \\
\hline Key & \multicolumn{2}{|c|}{ Minerals of secondary origin } & & & & After sprinkling \\
\hline $\mathrm{CC}$ & Calcite & $\mathrm{CaCO}_{3}$ & ++ & +++ & +++ & $\mathrm{CO}_{2}$ in air \\
\hline $\mathrm{CCH}$ & Hydrocalcite & $\mathrm{CaCO}_{3} \cdot \mathrm{H}_{2} \mathrm{O}$ & - & + & - & $\mathrm{CO}_{2}$ in air \\
\hline Po & Portlandite & $\mathrm{Ca}(\mathrm{OH})_{2}$ & + & - & - & Slaked only \\
\hline Et & Ettringite & $\mathrm{Ca}_{6} \mathrm{Al}_{2}\left(\mathrm{SO}_{4}\right)_{3}(\mathrm{OH})_{12} \cdot 26 \mathrm{H}_{2} \mathrm{O}$ & + & ++++ & +++ & Recombination \\
\hline $\mathrm{Hc}$ & Hydrocalumite & $\mathrm{Ca}_{2} \mathrm{Al}(\mathrm{OH})_{6} \mathrm{Cl} \cdot 2 \mathrm{H}_{2} \mathrm{O}$ & + & & & Recombination \\
\hline$(\mathrm{Kv})$ & L (Kovdorskite) & $\mathrm{Mg}_{2}\left(\mathrm{PO}_{4}\right)(\mathrm{OH}) \cdot 3 \mathrm{H}_{2} \mathrm{O}$ & $(+)$ & - & - & Recombination \\
\hline $\mathrm{Vr}$ & Vermiculite & $\mathrm{Mg}_{3} \mathrm{Si}_{4} \mathrm{O}_{10}(\mathrm{OH})_{2}$ & + & - & $(+)$ & Recombination \\
\hline
\end{tabular}

It should be stressed that raw PS-ashes are not completely amorphous, but abundant in crystalline phases-quite different from conventional geopolymer fillers such as metakaolin, water quenched blast furnace slag, coal fly ash, and so on.

\subsection{Physical Properties of PS-Ash-Based Geopolymer}

As shown in Table 4, for the \#0 and \#1 liquors, adequate values of L/F of PS-ash based geopolymer were from 1 to 1.5, depending on filler characters, particularly on specific surface areas and porous textures. Incidentally, a standard L/F is 0.4 for ordinary geopolymers in pastes [35]. OTs2 showed extremely slow setting with L/F 1.0, taking overnight, presumably due to the presence of so much chlorine, in addition to low specific surface area, so the specimen preparation for OTs2 was skipped in 
the present experiment. Other PS-ash-based geopolymer mixtures set within 40 min. Retarding effects of chlorine are recently confirmed by the experiment of using $\mathrm{NaCl}$ (Ichimiya, K., 2016, personal communication).

Table 4. Resultant flexural strength and bulk density of PS-ash-based geopolymers.

\begin{tabular}{|c|c|c|c|c|c|c|}
\hline \multirow{2}{*}{ Filler } & \multirow{2}{*}{ Key $^{1}$} & \multirow{2}{*}{$\frac{\text { L/F }}{\text { \#0 Liquor }}$} & \multirow{2}{*}{$\begin{array}{c}\text { Flexural Strength, } 4 \mathrm{wk}^{2} \\
(\mathrm{MPa})\end{array}$} & \multicolumn{3}{|c|}{ Bulk Density $\left(\mathrm{g} / \mathrm{cm}^{3}\right)$} \\
\hline & & & & 4 wk $\left(D_{0}\right)$ & $4+2 \mathrm{wk}\left(\mathrm{D}_{1}\right)$ & $12,24 \mathrm{wk}\left(\mathrm{D}_{2}, \mathrm{D}_{3}\right)^{3}$ \\
\hline \multirow[t]{2}{*}{ OTo3 } & $0-1$ & 1.5 & 1.19 & 1.29 & 0.85 & 0.82 \\
\hline & $0-1 S C$ & 1.5 & 1.22 & 1.29 & 0.84 & 0.82 \\
\hline \multirow[t]{3}{*}{ N45 } & $0-3$ & 1.2 & 0.82 & 1.50 & 1.10 & 0.98 \\
\hline & $0-3 S C$ & 1.2 & 0.99 & 1.49 & 1.08 & 0.97 \\
\hline & & \#1 liquor & & & & \\
\hline \multirow[t]{2}{*}{ OTo3 } & 1-1 & 1.5 & 1.19 & 1.56 & 1.04 & 1.02 \\
\hline & 1-1SC & 1.5 & 1.07 & 1.58 & 1.05 & 1.02 \\
\hline \multirow[t]{2}{*}{ N45 } & $1-3$ & 1.2 & 1.51 & 1.52 & 1.05 & 0.97 \\
\hline & $1-3 S C$ & 1.2 & 1.19 & 1.54 & 1.05 & 0.98 \\
\hline
\end{tabular}

${ }^{1} \mathrm{SC}: \mathrm{Sr}\left(\mathrm{NO}_{3}\right)_{2}$ and $\mathrm{CsNO}_{3}$ added as surrogate, and no SC indicating Plain. 0-2, 0-2SC, 1-2, 1-2SC of OTo2 with L/F 1.0 were not indicated here, since hardened bodies were not prepared. Refer to the text; ${ }^{2}$ wk: weeks;

${ }^{3}$ After 12 weeks, no more marked change in bulk density was observed.

It should be noted that when the \#0 liquor was applied, the OTo3-based geopolymer mixtures swelled. Eventually, many pores of foaming origin were observed in the hardened specimens (Figure 4), resulting in smaller bulk densities, as indicated in Table 4. Presumably, free Al metal is included in this kind of PS-ash. The origin of the Al metal would be Al-laminated appliances (such as food containers), which might slip into the RDF used in the boiler plant of OTo3. However, at this moment, the Al metal could not be observed, even under the high power of scanning electron microscopy and energy dispersive spectroscopy (SEM-EDS), which is probably disseminated at the nanometer scale in the ash. Hydrogen gas is generated due to the high $\mathrm{pH}$ circumstances of the \#0 liquor. To the contrary, no swelling was observed for the \#1 liquor without mixing the caustic soda solution. Incidentally, this type of swelling is also reported for an RDF-ash [36] and hydrogen generation is confirmed by gas chromatography (Goda, H., 2012, oral communication).

Flexural strength of this lightweight material was relatively high, compared to the other non-swelled materials. It is postulated that nitride ions suppress the development of strength to a certain degree, due to the $\mathrm{pH}$-lowering action of alkaline liquors [31,35]. However, in this study, this phenomenon was restricted to the specimens mixed with the \#1 liquor.

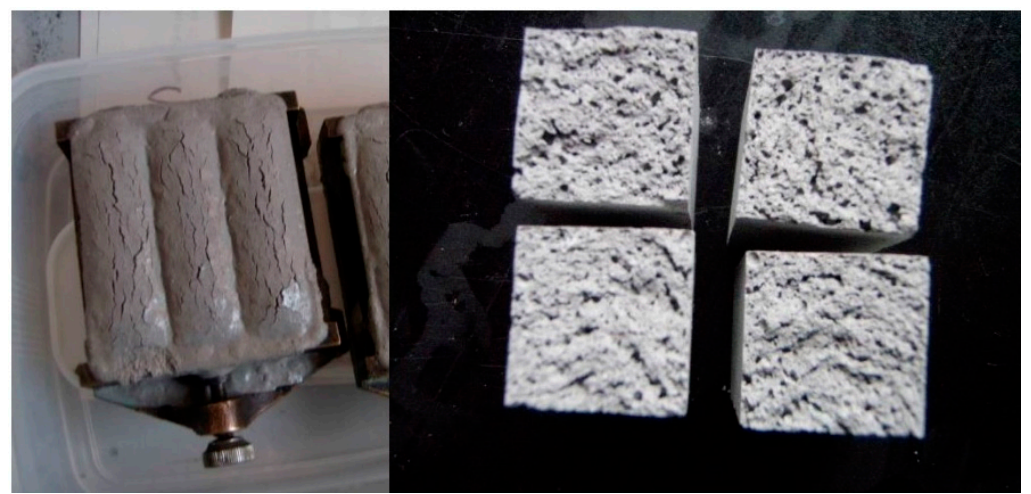

Figure 4. Swelling of hardened specimens and cross section of 0-1 specimen derived from OTo3 filler and \#0 liquor.

\subsection{XRD Results of Hardened Geopolymer}

For the plain specimens, XRD diagrams are represented in Figure 5 for the \#0 and \#1 liquors, respectively. Quartz and calcite remained more or less intact, irrespective of sample species. However, 
judging from the variation of peak heights, some part of these minerals were reacted and diminished in highly alkaline circumstances, even for quartz. Quartz decrease was also observed in the literature [5]. Ettringite and anhydrite were not detected any more, and neither were anorthite and vermuculite. Instead, the formation of carbonate ettringite was observed, irrespective of specimen species. It is noted that magnesian calcite, $(\mathrm{Ca}, \mathrm{Mg}) \mathrm{CO}_{3}$, was identified for 0-1 specimen, of which peaks are located just a little bit higher than the $2 \theta$ angles of calcite, $\mathrm{CaCO}_{3}$, as shoulders. Peak patterns of magnesian calcite are quite different from dolomite, $\mathrm{Ca}, \mathrm{Mg}\left(\mathrm{CO}_{3}\right)_{2}$. Formation of faujasite, a member of zeolite family, was observed for 0-1 and 1-3 specimens. Other identified minerals are pirssonite, burkeite, and thenerdite, depending on specimens-all formed accompanied with the geopolymerization of mixed alkaline liquors.

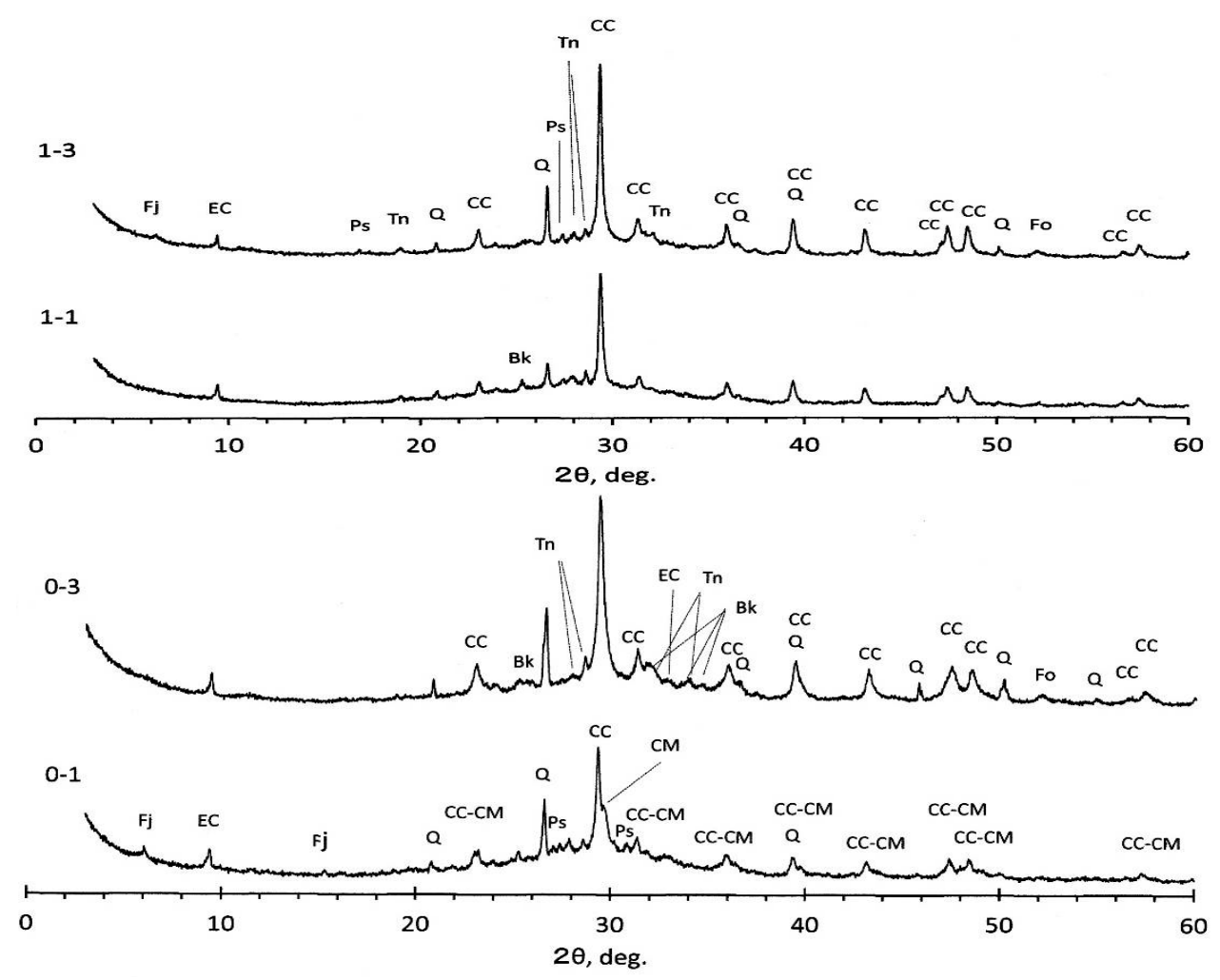

Figure 5. XRD diagrams of hardened bodies. Specimen keys refer to Table 4 , and mineral keys refer to Tables 3 and 5.

It is more plausible that the forsterite identified for specimens 0-3 and 1-3 might be a primary origin formed in the boiler. This mineral peaks might be concealed with anhydrite peaks in raw PS-ashes, and appeared intact according to the disappearance of anhydrite. Other than the crystalline phases mentioned above, there are amorphous phases more or less depending on specimens as so far postulated, judging from some humps around $2 \theta=30^{\circ}$. For SC-GP specimens, no marked differences from plain specimens were observed, probably due to lower-level dosages of the surrogates. However, according to literature using metakaolin filler under higher level presence of nitrates, the formation of sodalite and cancrinite was reported as nitrate-bearing phases in addition to zeolite A and zeolite $\mathrm{X}$, depending on $\mathrm{NaOH}$ concentrations [37].

Talking again about the faujasite, naturally-occurring faujasite generally has the chemical formula $\left(\mathrm{Na}_{2}, \mathrm{Ca}, \mathrm{Mg}\right)_{3.5}\left(\mathrm{Al}_{7} \mathrm{Si}_{17} \mathrm{O}_{48}\right) \cdot 32 \mathrm{H}_{2} \mathrm{O}$, in which the $\mathrm{S} / \mathrm{N}\left(\mathrm{SiO}_{2} / \mathrm{Na}_{2} \mathrm{O}\right)$ molar ratio is 4.86 . Incidentally, according to literature, naturally occurring faujasite has an $\mathrm{S} / \mathrm{N}$ of around 4.5 [38]. It is well-known that synthetic faujasite is classified by $\mathrm{S} / \mathrm{N}$ into zeolite $\mathrm{X}$ (lower than 3.0) and zeolite $\mathrm{Y}$ (higher than 3.0). XRD patterns represented in Figure 5 show that faujasite patterns are close to $\mathrm{Na}_{2} \mathrm{Al}_{2} \mathrm{Si}_{2.4} \mathrm{O}_{8.8} \cdot 6.7 \mathrm{H}_{2} \mathrm{O}$, 
where the $\mathrm{S} / \mathrm{N}$ is 2.4, so the formation of zeolite $\mathrm{X}$ is more plausible, suggesting that the incorporation of Na-Al combination is large in the faujasite structure.

\subsection{Reaction Process of PS-Ash-Based Geopolymers}

Resultant minerals are summarized in Table 5, classified into three categories. The first is the intrinsic minerals of primary origin formed in boilers. The second is the extrinsic minerals of secondary origin formed due to the water sprinkling. The third is relevant to the geopolymerization of alkaline liquors with the minerals included in the PS-ashes.

Referring to the hardening process of PS-ashes, the primary and the secondary minerals react with the alkaline liquors so that the recombination takes place, and minerals peculiar to the geopolymerization form. Thereby, forsterite may remain intact, while quartz and calcite may remain partially intact. Other minerals were completely consumed to yield a group of minerals called GP-minerals in Table 5, which are carbonate ettringite, faujasite, pirssonite, burkeite, and thenerdite, and sometimes magnesian calcite, other than amorphous gels which are truly matrices. The species of GP-minerals are dependent on the PS-ashes and alkaline liquors used. It is noteworthy to refer to the amorphous phases peculiar to geopolymers, which are currently believed to consist of two distinct phases-so called C-A-S-H gels and N-A-S-H gels-where $\mathrm{C}, \mathrm{A}, \mathrm{S}, \mathrm{H}$, and $\mathrm{N}$ denote $\mathrm{CaO}$, $\mathrm{Al}_{2} \mathrm{O}_{3}, \mathrm{SiO}_{2}, \mathrm{H}_{2} \mathrm{O}$, and $\mathrm{Na}_{2} \mathrm{O}$, respectively. It is considered that in Ca-rich geopolymer systems, C-A-S-H is stable, while N-A-S-H is unstable, due to the occurrence of an ion exchange of $\mathrm{Ca}^{2+}$ for $\mathrm{Na}^{+}$. Accordingly, N-A-S-H turns gradually to C-A-S-H and eventually diminishes [39-42]. Strictly speaking, initial C-A-S-H and N-A-S-H may finally become $(\mathrm{Ca}, \mathrm{N})-\mathrm{A}-\mathrm{S}-\mathrm{H}$ gels after the ion exchange.

\subsection{Immobiization Ratios of $\mathrm{Sr}^{2+}$ and $\mathrm{Cs}^{+}$}

Results of the $4+2$ week age samples are tabulated in Table 6 , together with relevant data for calculations. High immobilization ratios of $\mathrm{Sr}^{2+}$ and $\mathrm{Cs}^{+}$were reached for 0-1SC and 1-1SC, both using OTo3 as filler, whereas $\mathrm{Cs}^{+}$immobilization was relatively low for 0-3SC and 1-3SC, both using N45 as filler. It should be noted that specimen 1-3SC showed over-scale, indicating poor immobilization of $\mathrm{Sr}^{2+}$, so more detailed measurements of ICP were skipped for this specimen. $\mathrm{Cs}^{+}$will be mentioned later. 
Table 5. Resultant -minerals in PS-ash based geopolymers in comparison with PS-ash minerals and whole reaction process.

\begin{tabular}{|c|c|c|c|c|c|c|c|c|}
\hline \multicolumn{5}{|c|}{ PS-ash Minerals } & & \multicolumn{3}{|c|}{ Minerals in PS-ash Based Geopolymers } \\
\hline Key & \multicolumn{2}{|c|}{ Minerals of primary origin } & \multirow{3}{*}{$\begin{array}{c}\text { Remark } \\
\begin{array}{c}\text { Partially intact } \\
\text { Consumed }\end{array}\end{array}$} & & Key & & \multirow[t]{2}{*}{ Remark } \\
\hline $\mathrm{Q}$ & Quartz & $\mathrm{SiO}_{2}$ & & $\Rightarrow$ & & Quartz & $\mathrm{SiO}_{2}$ & \\
\hline An & Anhydrite & $\mathrm{CaSO}_{4}$ & & & & & & \\
\hline At & Anorthite & $\mathrm{CaAl}_{2} \mathrm{Si}_{2} \mathrm{O}_{8}$ & Consumed & & & & & \\
\hline Fo & Forsterite & $\mathrm{Mg}_{2} \mathrm{SiO}_{4}$ & Remain intact & $\Rightarrow$ & & Forsterite & $\mathrm{Mg}_{2} \mathrm{SiO}_{4}$ & \\
\hline Tc & $\begin{array}{c}\text { Talc } \\
\text { Amornhous }\end{array}$ & $\mathrm{Mg}_{3}(\mathrm{OH})_{2} \mathrm{Si}_{4} \mathrm{O}_{10}$ & $\begin{array}{l}\text { Consumd } \\
\text { Recombination }\end{array}$ & & & & & \\
\hline & Amorphous & & Recombination & & & & & \\
\hline Key & \multicolumn{2}{|c|}{ Minerals of secondary origin } & & & & & & \\
\hline $\mathrm{CC}$ & Calcite & $\mathrm{CaCO}_{3}$ & Partially intact & $\Rightarrow$ & & Calcite & $\mathrm{CaCO}_{3}$ & \\
\hline $\mathrm{CCH}$ & Monohydrocalcite & $\mathrm{CaCO}_{3} \cdot \mathrm{H}_{2} \mathrm{O}$ & Consumed & & $\mathrm{CM}$ & Magnesian calcite & $(\mathrm{Ca}, \mathrm{Mg}) \mathrm{CO}_{3}$ & Insoluble \\
\hline Po & Portlandite & $\mathrm{Ca}(\mathrm{OH})_{2}$ & Consumed & & $\mathrm{EC}$ & Carbonate-ettringite ${ }^{2}$ & & Insoluble \\
\hline Et & Ettringite $^{1}$ & & Consumed & & $\mathrm{Fj}$ & Faujasite ${ }^{30}$ & & Insoluble \\
\hline $\mathrm{HC}$ & Hydrocalumite & $\mathrm{Ca}_{2} \mathrm{Al}(\mathrm{OH})_{6} \mathrm{Cl} \cdot 2 \mathrm{H}_{2} \mathrm{O}$ & Consumed & & Ps & Pirssonite & $\mathrm{Na}_{2} \mathrm{Ca}\left(\mathrm{CO}_{3}\right)_{2} \cdot 2 \mathrm{H}_{2} \mathrm{O}$ & Sparingly soluble \\
\hline$(\mathrm{Kv})^{4}$ & (Kovdorskite) & $\mathrm{Mg}_{2}\left(\mathrm{PO}_{4}\right)(\mathrm{OH}) \cdot 3 \mathrm{H}_{2} \mathrm{O}$ & (Consumed) & & $\mathrm{Bk}$ & Burkeite & $\mathrm{Na}_{6}\left(\mathrm{CO}_{3}\right)\left(\mathrm{SO}_{4}\right)_{2}$ & Sparingly soluble \\
\hline $\mathrm{Vr}$ & Vermiculite & $\mathrm{Mg}_{3} \mathrm{Si}_{4} \mathrm{O}_{10}(\mathrm{OH})_{2}$ & Consumed & & $\mathrm{Tn}$ & Thenerdite & $\mathrm{Na}_{2} \mathrm{SO}_{4}$ & Soluble \\
\hline & Alkaline liquor & $\mathrm{Na}_{2} \mathrm{O}-\mathrm{SiO}$ & $-\mathrm{H}_{2} \mathrm{O}$ & $\Rightarrow$ & & Amorphous & C-A-S-H, N-A-S-H & \\
\hline
\end{tabular}

${ }^{1} \mathrm{Ca}_{6} \mathrm{Al}_{2}\left(\mathrm{SO}_{4}\right)_{3}(\mathrm{OH})_{12} \cdot 26 \mathrm{H}_{2} \mathrm{O}_{2}^{2} \mathrm{Ca}_{6} \mathrm{Al}_{2}\left(\mathrm{CO}_{3}\right)_{3}(\mathrm{OH})_{12} \cdot 26 \mathrm{H}_{2} \mathrm{O}_{3}^{3}\left(\mathrm{Na}_{2}, \mathrm{Ca}, \mathrm{Mg}\right)_{3}\left(\mathrm{Al}_{7} \mathrm{Si}_{17} \mathrm{O}_{48}\right) \cdot 32 \mathrm{H}_{2} \mathrm{O}^{*}{ }^{4}$ Presence suspected. 
Table 6. Resultant immobilization ratios of strontium and cesium for $4+2$ week age specimens with some relevant data.

\begin{tabular}{|c|c|c|c|c|c|c|c|}
\hline & \multirow{2}{*}{$\%$ Filler } & To $12.5 \mathrm{~g}$ & Surrogates, & $\mathrm{Sr}^{2+}$ & $\mathrm{Cs}^{+}$ & $\mathrm{ICP}, 421 \mathrm{~nm}$ & $\mathrm{ICP}, 459 \mathrm{~nm}$ \\
\hline & & Sample (g) & as Nitrate $(\mathrm{mg})$ & (mg) & (mg) & $\mathrm{Sr}^{2+}(\mathrm{ppb})$ & $\mathrm{Cs}^{+}(\mathrm{ppb})$ \\
\hline \multicolumn{8}{|l|}{ \#0 liquor } \\
\hline $0-1 S C$ & 61.43 & 7.68 & 76.8 & 31.8 & 52.4 & 530 & 11,580 \\
\hline $0-3 S C$ & 62.74 & 7.84 & 78.4 & 32.5 & 53.5 & 450 & 121,800 \\
\hline \multicolumn{8}{|l|}{ \#1 liquor } \\
\hline $1-1 \mathrm{SC}$ & 60.19 & 7.52 & 75.2 & 31.1 & 51.3 & 4400 & 14,040 \\
\hline \multirow[t]{3}{*}{$1-3 S C$} & 66.67 & 8.33 & 83.3 & 34.5 & 56.8 & Scale over & 131,500 \\
\hline & \multicolumn{2}{|c|}{ To $125 \mathrm{~g}$ leaching solution } & \multicolumn{2}{|c|}{ Immobilization ratio SC-GP } & & \multicolumn{2}{|c|}{ Immobilization ratio SC-GP-Slag } \\
\hline & $\mathrm{Sr}^{2+}(\mu \mathrm{g})$ & $\mathrm{Cs}^{+}(\mu \mathrm{g})$ & $\mathrm{Sr}^{2+}(\%)$ & $\mathrm{Cs}^{+}(\%)$ & & $\mathrm{Sr}^{2+}(\%)$ & $\mathrm{Cs}^{+}(\%)$ \\
\hline \#0 liquor & & & & & & \#0 liquor & \\
\hline 0-1SC & 66.25 & 1447.5 & 99.79 & 97.24 & & 98.38 & 97.38 \\
\hline 0-3SC & 56.25 & $15,225.0$ & 99.83 & 71.54 & & 93.19 & 97.36 \\
\hline \#1 liquor & & & & & & \#1 liquor & \\
\hline $1-1 S C$ & 550 & 1755.0 & 98.23 & 96.58 & & 97.60 & 100 \\
\hline $1-3 S C$ & - & $16,437.5$ & - & 71.06 & & 97.11 & 99.48 \\
\hline
\end{tabular}

Regarding the immobilization mechanisms of $\mathrm{Sr}^{2+}$ and $\mathrm{Cs}^{+}$, two possibilities are considered. One is that these ions are incorporated into faujasite and the other is into geopolymer gels (GP-gels). Faujasite would accommodate both $\mathrm{Sr}^{2+}$ and $\mathrm{Cs}^{+}$, since it consists of sodalite cages with openings of $0.74 \mathrm{~nm}$ in diameter. Incidentally, according to Shannon and Prewitt [43], ionic radii of $\mathrm{Sr}^{2+}$ and $\mathrm{Cs}^{+}$ are $0.118-0.144 \mathrm{~nm}$ and $0.167-0.188 \mathrm{~nm}$, respectively, depending on coordination numbers from 6-hold to 12-hold. Gobbinsite, $\left(\mathrm{Na}, \mathrm{Ca}_{0.5}\right)_{6}\left(\mathrm{Al}_{6} \mathrm{Si}_{10}\right) \mathrm{O}_{32} \cdot 12 \mathrm{H}_{2} \mathrm{O}$ - a zeolite family mineral一was also identified as a candidate mineral in a previous study [31]. However, judging from XRD peak intensities, the formation of faujasite is in very small quantities, and the formation of GP-gels is prevalent due to the polycondensation of applied alkaline liquors.

It is postulated that there are two kinds of GP-gels-C-A-S-H and N-A-S-H [39-42]. N-A-S-H is considered to be unstable under the co-presence of C-A-S-H, due to the ion exchange of $\mathrm{Ca}^{2+}$ for $\mathrm{Na}^{+}$. $\mathrm{Sr}^{2+}$ may be preferentially incorporated into C-A-S-H. We considered at the moment that the high $\mathrm{MgO}$ content of specimens 1-3SC (Table 1) may interfere the stable formation of C-A-S-H in young ages, so 1-3SC showed over-scale for $\mathrm{Sr}^{2+}$. Incidentally, the stability and instability of GP-gels are also called "a complex multistep reaction process", leading to a phase-mixed product in the case of N-A-S-H [44]. That is, a non-equilibrium-to-equilibrium transition of GP-gels. However, little has been studied in the case of C-A-S-H.

For $\mathrm{Cs}^{+}$incorporation, N-A-S-H and faujasite may play an important role. However, it is predictive that N-A-S-H becomes unstable with elapsed time. Therefore, the immobilization ratio of $\mathrm{Cs}^{+}$may decrease with the ion exchange, resulting in some $\mathrm{Cs}^{+}$depletion. In the long run, however, with the formation of new C-A-S-H phase, $(\mathrm{C}, \mathrm{N})-\mathrm{A}-\mathrm{S}-\mathrm{H}, \mathrm{Cs}^{+}$may be again incorporated. In order to confirm this hypothesis, immobilization ratios of prolonged ages were measured up to 24 weeks, nearly 6 months. The results are shown in Table 7.

Table 7. Summary of immobilization ratios as a function of material age.

\begin{tabular}{ccccccccc}
\hline & $\mathbf{S r}^{\mathbf{2 +}}$ & $\mathbf{4 + 2} \mathbf{w k}$ & $\mathbf{1 2} \mathbf{w k}$ & $\mathbf{2 4} \mathbf{w k}$ & $\mathbf{C s}^{+}$ & $\mathbf{4 + 2} \mathbf{w k}$ & $\mathbf{1 2} \mathbf{w k}$ & $\mathbf{2 4} \mathbf{w k}$ \\
\hline 0-1SC & \#0 liquor & 99.79 & 99.80 & 99.89 & $\# 0$ liquor & 97.24 & Over-scale & 97.48 \\
0-3SC & & 99.83 & 99.83 & 99.88 & & 71.54 & Over-scale & 98.30 \\
1-1SC & \multirow{2}{*}{$\#$ liquor } & 98.23 & 98.27 & 98.59 & $\# 1$ liquor & 96.58 & 90.95 & 98.77 \\
1-3SC & & Over-scale & 91.73 & Over-scale & & 71.06 & 46.16 & 95.65 \\
\hline
\end{tabular}

For $\mathrm{Sr}^{2+}$, higher immobilization ratios were generally maintained, irrespective of material age. However, 1-3SC showed unstable immobilization ratios. Strangely, we found that it turned dramatically up to $91.73 \%$ at 12 week of age, but it turned down again at 24 weeks of age, suggesting 
unstable incorporation of $\mathrm{Sr}^{2+}$ in this mixture. As mentioned, the high $\mathrm{MgO}$ content may be a cause of this instability, and there also may be some transitional stages in the evolution of C-A-S-H gels with elapsed time.

For $\mathrm{Cs}^{+}$, decreasing immobilization ratios were found at 12 weeks of age, as expected, and this phenomenon is extremely remarkable for the \#0 liquor. However, these ratios again rose up at 24 weeks of age, as expected.

As a whole, 1-1SC applying \#1 liquor exhibited stable immobilization ratios, irrespective of material ages. To prevent the fluctuation of immobilization ratios, one of the measures would be high-temperature curing, which accelerates the polycondensation reactions to yield stable GP-gels in a short period of time. Incidentally, high immobilization ratios were also reported for $\mathrm{Cs}^{+}$incorporated into alkali-activated fly ash matrices cured at $85^{\circ} \mathrm{C}$ and $120^{\circ} \mathrm{C}$, reaching $98.56 \%-99.78 \%$ immobilization ratios that were analyzed by toxic characteristic leaching procedure (TCLP), using the $\mathrm{pH} 2.88$ leaching solution of glacial acetic acid [35]. Retentions of $95.2 \%$ and $81.4 \%$ are reported, respectively, for $\mathrm{Sr}^{2+}$ and $\mathrm{Cs}^{+}$in $0.01 \mathrm{M} \mathrm{NaOH}$ solution, using magnetic zeolite nanocomposites [45].

Finally, we tentatively tried to convert the hardened SC-GP into slags to reduce volumes. Fusion temperature and duration were $1400{ }^{\circ} \mathrm{C}-1 \mathrm{~h}$ for $0-1 \mathrm{SC}$ and $1-1 \mathrm{SC}$, and $1300^{\circ} \mathrm{C}-1 \mathrm{~h}$ for $0-3 S \mathrm{C}$ and 1-3SC, respectively. Moistures of GP-liquor origin as well as evaporates represented as LOI in Table 1 were taken into account in calculations. Results were tabulated at the right-bottom corner of Table 6, showing high immobilization ratios for both $\mathrm{Sr}^{2+}$ and $\mathrm{Cs}^{+}$. Therefore, slag conversion would be one of the options for eternal burials as proposed in a previous study [31].

\subsection{XANES}

XANES spectra of the $\mathrm{K}$ absorption edge of strontium for SC-GP specimens of $4+2$ week age were compared with the spectra of the standard samples of $\mathrm{SrCl}_{2}, \mathrm{SrCO}_{3}$, and slawsonite, $(\mathrm{Sr}, \mathrm{Ca}) \mathrm{Al}_{2} \mathrm{Si}_{2} \mathrm{O}_{8}$ ). The former two are reagents, and slawsonite is a naturally-occurring mineral involving strontium in the structure from Sarusaka, Kochi, Japan. As shown in Figure 6, spectra are relatively well-separated from each other for the standard samples, indicating that the chemical states of $\mathrm{Sr}^{2+}$ were different among $\mathrm{SrCl}_{2}, \mathrm{SrCO}_{3}$, and slawsonite. On the other hand, XANES spectra of strontium in the SC-GP specimens are almost in a bundle, indicating that chemical states of $\mathrm{Sr}^{2+}$ in these specimens are nearly identical. The obtained results indicate that the chemical states of $\mathrm{Sr}^{2+}$ in SC-GP specimens resemble that in slawsonite. Incidentally, in slawsonite, $\mathrm{Sr}^{2+}$ is surrounded by $\mathrm{O}^{2-}$ in 7-hold coordination with a mean M-O distance of $0.263 \mathrm{~nm}$ [46]. Deducting the ionic radius of $\mathrm{O}^{2-}$, which is $0.126 \mathrm{~nm}$, after Shannon and Prewitt [43], $0.137 \mathrm{~nm}$ is obtained as the net ionic radius of $\mathrm{Sr}^{2+}$. However, this ionic radius of $\mathrm{Sr}^{2+}$ corresponds to 8-hold coordination, according to [47].

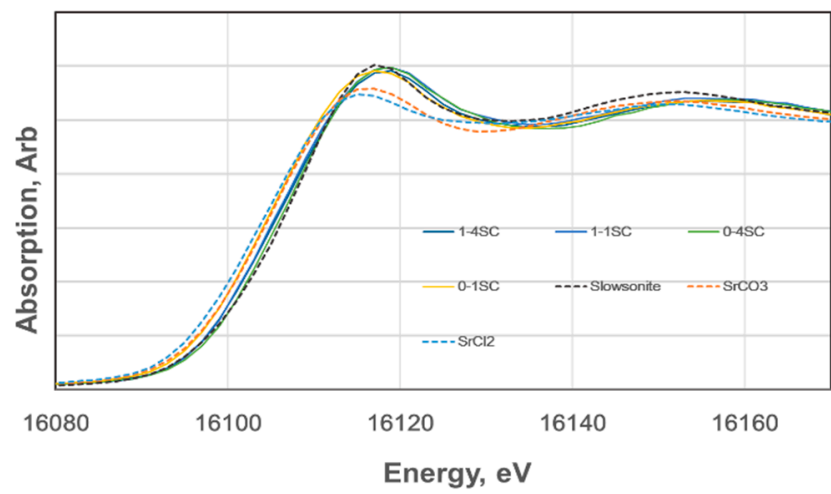

Figure 6. X-ray absorption near edge structure (XANES) spectra of hardened bodies for strontium K-edge. 
It should be stressed again that 1-3SC showed less capability of $\mathrm{Sr}^{2+}$ at $4+2$ and 24 weeks of age. However, it was found that the immobilization ratio became enhanced to $91.73 \%$ at the intermediate age of 12 weeks. XANES measurements were performed by using $4+2$ week age specimens, but there is about one month time lag for the actual measurements, due to time sharing schedules of the facility. Therefore, it is difficult, at the moment, to tell the spectra of 1-3SC, whether coming from embryo stage of C-A-S-H gels due to slow coagulation or coming from well-developed and matured C-A-S-H or (C, N)-A-S-H gels. According to literature $[48,49], \mathrm{Sr}^{2+}$ incorporations are unstable in metakaolin-based geopolymers, in which N-A-S-H gels form preferentially. In other words, depletion of $\mathrm{Sr}^{2+}$ takes place to yield $\mathrm{SrCO}_{3}$ in air, but no depletion of $\mathrm{Cs}^{+}$occurs, meaning $100 \%$ incorporation of $\mathrm{Cs}^{+}$into N-A-S-H. Formation of $\mathrm{Sr}(\mathrm{OH})_{2}$ and as $\mathrm{SrCO}_{3}$ is also reported in the metakaolin-based geopolymer, where the clinoptilolite zeolite encapsulating $\mathrm{Sr}^{2+}$ and $\mathrm{Cs}^{+}$is mixed [50].

At the moment, no spectral profiles corresponding to $\mathrm{SrCO}_{3}$ were observed in the XANES spectra, even for 1-3SC, which showed highly fluctuating immobilization ratios of $\mathrm{Sr}^{2+}$ with elapsed time, as mentioned. Therefore, we concluded that no depletion of $\mathrm{Sr}^{2+}$ took place in our SC-GP specimens and that the fluctuations may be attributed to the transitional GP-gel structures of C-A-S-H or (C, N)-A-S-H. That is, for instance, differences in degrees of polymerization and/or differences in tetrahedral order-disorder configurations, which would be sensitive to acidic conditions of the leaching test. The XANES technique will become a powerful measure to clarify the bonding and coordination circumstances of matrix gels in geopolymers.

\section{Conclusions}

Paper mill wastes-PS-ashes_can be solidified at ambient temperature by geopolymerization technique, by mixing with alkaline liquors designated as \#0 liquor (having an aqueous Na-metasillicate composition) or \#1 liquor (having aqueous $\mathrm{Na}$-disilicate composition), independently. It has been found that PS-ashes consist of a high quantity of crystalline phases, accompanied with some amorphous phases such that they can be regarded as semi-crystalline fillers, quite different from the conventional fillers of metakaolin, glassy blast furnace slag, and glassy coal fly ash, which consist of almost entirely amorphous materials.

Primarily, solidification and strength tests were carried out, preparing solidified paste specimens, plain, and SC-GP-containing non-radioactive $\mathrm{Sr}\left(\mathrm{NO}_{3}\right)_{2}$ and $\mathrm{CsNO}_{3}$ as surrogates. Specimens were cured at $20{ }^{\circ} \mathrm{C}-100 \% \mathrm{RH}$ for 4 weeks. Subsequently, they were air-dried up to 24 weeks of age. Finally, immobilization ratios of $\mathrm{Sr}^{2+}$ and $\mathrm{Cs}^{+}$were determined for the SC-GP specimens at 6, 12 and 24 weeks, respectively, by leaching test with $\mathrm{pH} 4.01$ buffer solution. The following conclusions are summarized.

(1) Constituent minerals of the PS-ashes are classified into two groups: the primary or intrinsic minerals formed in boilers, and the secondary or extrinsic minerals due to water sprinkling. The primary and secondary minerals decompose into so-called GP-minerals during the geopolymerization process.

(2) Hazardous waters contaminated with radioisotopes can be solidified by geopolymer technique, making use of the porous textures of PS-ashes, which can absorb much water. The leaching test generally showed high immobilization ratios-98\%-99\% and $97 \%-98 \%$ for $\mathrm{Sr}^{2+}$ and $\mathrm{Cs}^{+}$, respectively, depending on material ages, alkaline liquors, and filler species. However, some specimens showed highly fluctuating immobilization ratios for both $\mathrm{of} \mathrm{Sr}^{2+}$ and $\mathrm{Cs}^{+}$with elapsed time.

(3) XANES spectra of strontium K-edge of SC-GP specimens were measured at 6 weeks of age, and were discussed in comparison with the slawsonite spectrum. The obtained results showed that chemical environments of $\mathrm{Sr}^{2+}$ incorporated into the PS-ash based GP-gels are similar to slawsonite. 
Author Contributions: Zhuguo Li, Toshihiko Ohnuki and Ko Ikeda designed the experiments. Toshihiko Ohnuki took XANES data. Zhuguo Li and Ko Ikeda took other experimental data and analyzed. Zhuguo Li wrote the paper under the supervision of Ko Ikeda.

Conflicts of Interest: The authors declare no conflict of interest.

\section{References}

1. Vallepu, R.; Nakamura, Y.; Komatsu, R.; Ikeda, K. Preparation of forsterite by the geopolymer technique-Gel compositions as a function of $\mathrm{pH}$ and crystalline phases. J. Sol Gel Sci. Technol. 2005, 35, 107-114. [CrossRef]

2. Vallepu, R.; Mikuni, A.; Komatsu, R.; Ikeda, K. Synthesis of liebenbergite nano-crystallites from silicate precursor gels prepared by geopolymerization. J. Min. Pet. Sci. 2005, 100, 159-167. [CrossRef]

3. Ikeda, K.; Onikura, K.; Nakamura, Y.; Vedanand, S. Optical spectra of Nickel-bearing silicate gels prepared by the geopolymer technique, with special reference to the low-temperature formation of liebenbergite $\left(\mathrm{Ni}_{2} \mathrm{SiO}_{4}\right)$. J. Am. Ceram. Soc. 2001, 84, 1717-1720. [CrossRef]

4. Ikeda, K. Preparation of Willemite and Its Application to Phosphers. Patent of Japan No. 4923242, 17 February 2012.

5. Yamaguchi, N.; Nagaishi, M.; Kisu, K.; Nakamura, Y.; Ikeda, K. Preparation of monolithic geopolymer materials from urban waste incineration slags. J. Ceram. Soc. Jpn. 2013, 121, 847-854. [CrossRef]

6. Yamaguchi, N.; Ikeda, K. Preparation of geopolymeric materials from sewage sludge slag with special emphasis to the matrix compositions. J. Ceram. Soc. Jpn. 2010, 118, 107-112. [CrossRef]

7. Ikeda, K.; Mikuni, A. Chemistry of geopolymers and diversification of fillers to waste origin. ALIT Inform 2008, 3-4, 72-82, with Russian Translation in Parallel.

8. Hernandez-Jemenez, A.; Palomo, A.; Vazquez, T.; Vallepu, R.; Terai, T.; Ikeda, K. Alkaline activation of blends of metakaolin and calcium aluminate. J. Am. Ceram. Soc. 2008, 91, 1231-1236. [CrossRef]

9. Mikuni, A.; Komatsu, R.; Ikeda, K. Dissolution properties of some fly ash fillers applying to geopolymeric materials in alkali solution. J. Mater. Sci. 2007, 42, 2953-2957. [CrossRef]

10. Vallepu, R.; Fernández-Jiménez, A.; Terai, T.; Mikuni, A.; Palomo, A.; MacKenzie, K.J.D.; Ikeda, K. Effect of synthesis $\mathrm{pH}$ on the preparation and properties of K-Al-bearing silicate gels from solution. J. Ceram. Soc. Jpn. 2006, 114, 624-629. [CrossRef]

11. Ikeda, K.; Terai, T.; Vallepu, R.; Mikuni, A. Preparation of geopolymer monoliths in various proportions of sodium disilicate and caustic soda. In Proceedings of the 6th ISCC, Xi'an, China, 19-22 September 2006; Volume 1, pp. 674-678.

12. Mikuni, A.; Wei, C.; Komatsu, R.; Ikeda, K. Thermal alteration of kaolins and elution properties of calcined products in alkali solution. J. Soc. Inorg. Mater. Jpn. 2005, 12, 115-121.

13. Mikuni, A.; Wei, C.; Komatsu, R.; Ikeda, K. Thermal alteration of pyrophyllites and elution properties of the calcined pyrophyllite in alkali solution. J. Soc. Inorg. Mater. Jpn. 2005, 12, 191-199.

14. Feng, D.; Mikuni, A.; Hirano, Y.; Komatsu, R.; Ikeda, K. Preparation of geopolymeric materials from fly ash filler by steam curing with special reference to binder products. J. Ceram. Soc. Jpn. Spec. Issue Innov. Ceram. 2005, 113, 82-86. [CrossRef]

15. Iwahiro, T.; Komatsu, R.; Ikeda, K. Chemical compositions of gels prepared from sodium metasilicate and aluminum nitrate solutions. In Proceedings of the Geopolymers 2002, Melbourne, Australia, 28-29 October 2002; pp. 176-183.

16. Kihara, T.; Mikuni, A.; Nakamura, Y.; Komatsu, R.; Ikeda, K. Consolidation of pressurized fluidized bed combustion ash (PF-ash) by the geopolymer technique at ambient temperature. In Proceedings of the CIMTEC 2002, Science for New Technology of Silicate Ceramics, Florence, Italy, 14-18 July 2002; pp. 163-168.

17. Ikeda, K.; Nakamura, Y. Consolidation of quartz powder by the geopolymer technique. Korean J. Ceram. 2000, 6, 120-123.

18. Yamaguchi, N.; Kisu, K.; Ikeda, K. Preparation of Geopolymeric Materials Based on Sewage Sludge Slag. Patent of Japan No. 5435255, 20 December 2013.

19. Davidvits, J.; Comrie, D.C. Long term durability of hazardous toxic and nuclear waste disposals. In Proceedings of the Geopolymer '88, Compiègne, France, 1-3 June 1988; pp. 125-134. 
20. Vasil'eva, N.G.; Anshits, N.N.; Sharonova, O.M.; Burdin, M.V.; Anshits, A.G. Immobilization of cesium and strontium radionuclides in framework sluminosilicates with the use of porous glass ceramics matrices based on coal fly ash cenospheres. Glass Phys. Chem. 2005, 31, 637-647. [CrossRef]

21. Cozzi, A.D.; Bannochie, C.J.; Burket, P.R.; Crawford, C.L.; Jantzen, C.M. Immobilization of radioactive waste in fly ash besed geopolymers. In Proceedings of the World Coal Ash (WOCA) Conference, Denver, CO, USA, 9-12 May 2011; p. 9.

22. Cappelletti, P.; Rapisardo, G.; de Gennaro, B.; Colella, A.; Langella, A.; Graziano, S.F.; Bish, D.L.; de Gennaro, M. Immobilization of $\mathrm{Cs}$ and $\mathrm{Sr}$ in aluminosilicate matrices derived from natural zeolites. J. Nuclear Mater. 2011, 414, 451-457. [CrossRef]

23. Liguori, B.; Caputo, D.; Iucolano, F.; Aprea, P.; de Gennaro, B. Entrapping of Cs and Sr in heat-treated zeolite matrices. J. Nuclear Mater. 2013, 435, 196-201. [CrossRef]

24. Munthali, M.W.; Johan, E.; Aono, H.; Matsue, N. $\mathrm{Cs}^{+}$and $\mathrm{Sr}^{2+}$ adsorption selectivity of zeolites in relation to radioactive decontamination. J. Asian Ceram. Soc. 2015, 3, 245-250. [CrossRef]

25. Material-1, 2010. Follow up Investigation of Self-Motivation Project of Environmental Issues for Fiscal 2010, Materials of Japan Paper Association. Available online: www.jpa.gr.jp/docs/stats/followup.php (accessed on 18 May 2016). (In Japanese)

26. Material-2, 2014. "Outlined Report of Hydrothermal Consolidation of Paper Sludge", Materials, 7-1, of the $1_{\text {st }}$ Meeting of the Follow up of the Program for Effective Energy Production of Paper, Ministry of Economics and Industries of Japanese Government, and Nihon Paper Industries Co. Ltd. (In Japanese). Available online: www.meti.go.jp/policy/tech.../shigyou01_siryou_7-1.pdf (accessed on 18 May 2016).

27. Kido, Y.; Nishimoto, S.; Sato, A. Characteristics of paper sludge ash discharged from paper mills as for civil engineering materials. Mon. Rep. Inst. Civ. Eng. Dev. Hokkaido 2005, 631, 10-16. (In Japanese with English abstract)

28. Asada, M.; Ogawa, S.; Tutsumi, H. New geomaterial made from paper sludge ash and clayey soil. Res. Rep. Shimizu Constr. Co. Ltd. 2004, 80, 7-16. (In Japanese with English abstract)

29. Egusa, K.; Kaneco, S.; Dabwan, A.; Katsumata, H. Removal of turbidity in wastewater with coagulants based on paper sludge ash. Seikatsu Eisei 2010, 54, 330-335. (In Japanese with English abstract)

30. García, R.; de la Villa, V.; Vegas, I.; Frías, M.; Sánchez de Rojas, M.I. The pozzolanic properties of paper sludge waste. Const. Build. Mater. 2008, 22, 1484-1490. [CrossRef]

31. Ikeda, K.; Li, Z. Development of paper sludge ash-based geopolymer and application to the solidification of nuclear waste water. In Proceedings of the 14th ICCC, Beijing, China, 13-16 October 2015; Volume 6.

32. Li, Z.; Ikeda, K. Treatment of Contaminated Water. Patent of Japan No. 5669120, 26 December 2014.

33. Kitami, K.; Kusumi, Y. Fundamental Physical Chemistry; Sangyo Tosho: Tokyo, Japan, 1957; pp. $198-199$. (In Japanese)

34. Davidovits, J. Geopolymer, 2nd ed.; Institut Géopolymère: Saint-Quentin, France, 2008; pp. 369-370.

35. Fernandez-Jimenez, A.; Macphee, D.E.; Lachowski, E.E.; Palomo, A. Immobilization of cesium in alkaline activated fly ash matrix. J. Nuclear Mater. 2005, 346, 185-193. [CrossRef]

36. Harada, K. Presentation Materials of the Achievement of Geopolymer Research Group, Kitakyusyu, Japan. Geopolymers blended with RDF fly ash. 27 August 2013. (In Japanese). Available online: www.recycle-ken. or.jp (accessed on 18 May 2016).

37. Ofer-Rozovsky, E.; Arbel Haddad, M.; Bar Nes, G.; Katz, A. The formation of crystalline phases in metakaolin-based geopolymers in the presence of sodium nitrate. J. Mater. Sci. 2016, 51, 4795-4814. [CrossRef]

38. Stamires, D.N. Properties of the zeolite, faujasite, substitutional series: A review with new data. Clays Clay Miner. 1973, 21, 379-389. [CrossRef]

39. García-Lodeiro, I.; Fernández-Jiménez, A.; Palomo, A. Variation in hybrid cements over time. Alkaline activation of fly ash-portland cement blends. Cem. Concr. Res. 2013, 52, 112-122. [CrossRef]

40. García-Lodeiro, I.; Palomo, A.; Fernández-Jiménez, A.; Macphee, D.E. Compatibility studies between $\mathrm{N}-\mathrm{A}-\mathrm{S}-\mathrm{H}$ and C-A-S-H gels. Study in the ternary diagram $\mathrm{Na}_{2} \mathrm{O}-\mathrm{CaO}-\mathrm{Al}_{2} \mathrm{O}_{3}-\mathrm{SiO}_{2}-\mathrm{H}_{2} \mathrm{O}$. Cem. Concr. Res. 2011, 41, 923-931. [CrossRef]

41. Yip, C.K.; Lukey, G.C.; van Deventer, J.S.J. The coexistence of geopolymeric gel and calcium silicate hydrate at the early stage of alkaline activation. Cem. Concr. Res. 2005, 35, 1688-1697. [CrossRef] 
42. Macphee, D.; Garcia-Lodeiro, I. Activationof alumino silicates-Some chemical considerations. In Proceedings of the 2nd International Slag Valorisation Symposium, Leuven, Belgium, 18-20 April 2011; pp. 51-61.

43. Shannon, R.D.; Prewitt, C.T. Effective ionic radii in oxides and fluorides. Acta Cryst. 1969, B25, $925-955$. [CrossRef]

44. Provis, J.L.; van Deventer, J.S.J. Geopolymerization kinetics. 2. Reaction kinetic modeling. Chem. Eng. Sci. 2007, 62, 2318-2329. [CrossRef]

45. Faghihian, H.; Moayed, M.; Firooz, A.; Iravani, M. Synthesis of a novel magnetic zeolite nanocomposite for removal of $\mathrm{Cs}^{+}$and $\mathrm{Sr}^{2+}$ from aqueous solution: Kinetic equilibrium, and thermodynamic studies. J. Colloid Interface Sci. 2013, 393, 445-451. [CrossRef] [PubMed]

46. Griffen, D.T.; Ribbe, P.H.; Gibbs, G.V. The structure of slawsonite, a strontium analog of paracelsian. Am. Miner. 1977, 62, 31-35.

47. West, A.R. Solid State Chemistry and Its Applications, 2nd ed.; John Wiley: Chichester, UK, 2014; p. 518, Japanese translation, Kodansha, Tokyo, Japan, 2016.

48. Blackford, M.G.; Hanna, J.V.; Pike, K.J.; Vance, E.R.; Perera, D.S. Transmission electron microscopy and nuclear magnetic resonance studies of geopolymers for radioactive waste immobilization. J. Am. Ceram. Soc. 2007, 90, 1193-1199. [CrossRef]

49. Provis, J.L.; Walls, P.A.; van Deventer, J.S.J. Geopolymerization kinetics. 3. Effects of Cs and Sr salts. Chem. Eng. Sci. 2008, 63, 4480-4489. [CrossRef]

50. Kuenzel, C.; Cisneros, J.F.; Neville, T.P.; Vandeperre, L.J.; Simons, S.J.R.; Bensted, J.; Cheeseman, C.R. Encapsulation of $\mathrm{Cs} / \mathrm{Sr}$ contaminated clinoptilolite in geopolymers produced from metakaolin. J. Nuclear Mater. 2015, 466, 94-99. [CrossRef]

(C) 2016 by the authors; licensee MDPI, Basel, Switzerland. This article is an open access article distributed under the terms and conditions of the Creative Commons Attribution (CC-BY) license (http:/ / creativecommons.org/licenses/by/4.0/). 